\title{
Feelings experienced in hyperbaric oxygen therapy: the users' voice
}

\section{Sentimentos vivenciados na oxigenoterapia hiperbárica: a voz dos usuários}

\section{Sentimientos vividos en la oxigenoterapia hiperbárica: una voz de los usuarios}

\author{
Maria Samya Carvalho Machado1,2, Evanilda Souza de Santana Carvalho3, Rayssa Fagundes \\ Batista Paranhos ${ }^{4, *}$, Cintia Silva de Souza Costa
}

\section{ORCID IDS}

Machado MSC (D) https://orcid.org/0000-0002-4336-3827

Carvalho ESS (iD) https://orcid.org/0000-0003-4564-0768

Paranhos RFB (D) https://orcid.org/0000-0002-7690-6453

Costa CSS (D) https://orcid.org/0000-0002-5814-8433

\section{HOW TO CITE}

Machado MSC; Carvalho ESS; Paranhos RFB; Costa CSS. Feelings experienced in hyperbaric oxygen therapy: the users' voice. ESTIMA, Braz. J. Enterostomal Ther., 2020, 18: e1920. https://doi. org/10.30886/estima.v18.860_IN

\begin{abstract}
Objective: To characterize the feelings experienced by users of hyperbaric oxygen therapy (HBOT). Methods: Qualitative study, using multiparametric techniques for data collection such as the free word association technique, drawing-and-story procedure with theme and the semistructured interview. For the analysis, the discursive material, together with the visualization of the drawings and the responses of the word-free associations, was cross-referenced and the method of content analysis was employed, thus allowing the feelings experienced at HBOT to be portrayed. Results: The categories emerged: fear and anxiety; feeling of imprisonment and tiredness; happiness and confidence/hope, the latter being subdivided into trust in the therapy and in God. Conclusion: After, the first sessions and especially after the guidance and incentives from the professionals, the negative feelings were softened and gave way to satisfaction, followed by happiness in being able to return to family and social life and all this anchored in the feeling of hope and faith.
\end{abstract}

DESCRIPTORS: Nursing care; Hyperbaric oxygenation; Emotions; Qualitative research; Enterostomal therapy.

\section{RESUMO}

Objetivo: Caracterizar os sentimentos vivenciados pelos usuários da oxigenoterapia hiperbárica (OHB). Métodos: Estudo qualitativo, utilizando técnicas multiparamétricas para coleta de dados como a técnica de associação livre de palavras, procedimento desenhoestória com tema e a entrevista semiestruturada. Para a análise, o material discursivo, juntamente com a visualização dos desenhos e as respostas das associações livres de palavras, foi cruzado e empregado o método de análise de conteúdo permitindo, dessa forma, retratar os sentimentos vivenciados na OHB. Resultados: Emergiram as categorias: medo e ansiedade; sentimento de prisão e cansaço; felicidade e confiança/esperança, sendo que esta última subdividida em confiança na terapia e em Deus. Conclusão: Após as primeiras sessões e principalmente após as orientações e incentivos dos profissionais, os sentimentos negativos foram amenizados e cederam espaço para a satisfação, seguidos de felicidade em poder voltar ao convívio familiar e social e tudo isso ancorado no sentimento de esperança e fé.

DESCRITORES: Cuidados de enfermagem; Oxigenação hiperbárica; Emoções; Pesquisa qualitativa; Estomaterapia.

\footnotetext{
1. Hospital Clériston Andrade - Feira de Santana (BA), Brazil.

2. Cliof Oftalmoogia - Feira de Santana (BA), Brazil.

3. Universidade Estadual Feira de Santana - Feira de Santana (BA), Brazil.

4. Estomaclin Serviços Médicos, enfermagem e estomaterapia - Salvador (BA), Brazil.

5. Hiperbárica Feira de Santana - Feira de Santana (BA), Brazil.

*Correspondence author: rayssa.paranhos@gmail.com

Received: Mar. 12, 2020 | Accepted: Ago. 10, 2020
} 


\section{RESUMEN}

Objetivo: Objetivo: caracterizar las sensaciones que experimentan los usuarios de oxigenoterapia hiperbárica (OHB). Métodos: estudio cualitativo, uso de técnicas multiparamétricas para la recopilación de datos como técnica de asociación de palabras libre, procedimiento de dibujo-historia con tema y entrevista semiestructurada. Para el análisis, el material discursivo, junto con la visualización de los dibujos y las respuestas de las asociaciones de palabras libres, se cruzó y utilizó el método de análisis de contenido, manera, retrata los sentimientos experimentados en HBO. Resultados: Surgieron las categorías: miedo y ansiedad; sentimiento de prisión y cansancio; felicidad y confianza / esperanza, esta última subdividida en confianza en la terapia y en Dios. Conclusión: Después las primeras sesiones y principalmente después de la orientación e incentivos de los profesionales, se mitigaron los sentimientos negativos y dio paso a la satisfacción, seguida de la alegría de poder volver a la vida familiar y social y todo ello anclado en sentimiento de esperanza y fe.

DESCRIPTORES: Atención de Enfermería; Oxigenación hiperbárica; Emociones; Investigación cualitativa; Estomaterapia.

\section{INTRODUCTION}

Hyperbaric oxygen therapy (HBOT) is a therapy that offers oxygen at a purity of more than $99 \% \mathrm{v} / \mathrm{v}$ (volume percentage) in an environment with higher than atmospheric pressure between 2 and 3 AAT (above atmospheric tension) being usually employed 2.4-2.8 AAT for an average period of 60 to 90 minutes. This environment is obtained inside a chamber whose appearance resembles that of a submarine, where the patient receives a mask for which the oxygen will be administered1. Clinical indications are diverse, ranging from lung, vascular, ischemic and infection problems, to wounds in people with diabetes, extensive lesions such as Fournier, burns, radiodermites, among others. The adverse effects are related to pressure variation and oxygen toxicity such as dry cough, discomfort in the sinuses, ear barotrauma, tinnitus and, in rare exceptions, pulmonary edema. Contraindications are pneumothorax, fibrosis, pulmonary emphysema and heart failure ${ }^{1,2}$.

The recommendation is to apply HBOT daily, between 10 and 30 consecutive sessions, defined as indicated by the hyperbaric physician. The clinical need to be in the chamber every day associated with living with an illness that limits life leads to changes in lifestyle and generates diverse feelings.

The first HBOT session is a milestone: the individual, immersed in his feelings and emotions that accompany him throughout the pathological process, is faced with a possibility of a faster and more effective healing, which generates in him feelings of hope, anxiety and fear in the face of the unknown.

Thus, caring for people at the HBOT not only involves conducting the sessions, but includes issues such as beliefs, perceptions and meanings. Emotions experienced as well as cultural aspects cannot be disregarded in order to achieve holistic care and full adherence to treatment.

Health professionals and nursing students involved in the assistance provide technical care for the execution of the sessions, but also see themselves as agents of transformation in listening to the fears, doubts and uncertainty of what can occur in that environment, contributing to the success of the therapy. During this attendance, it was perceived that these people needed to be heard for the nursing care to be directed to the real necessities and not based on what the nursing believed as better. In this sense, the need to open up a space for therapeutic listening was perceived, and some questions arose to reflect: What are the feelings experienced by users of hyperbaric oxygen therapy? How is the process of inserting these individuals into therapy? And what are their expectations regarding the treatment? Responding to these questions, the objective was to characterize the feelings experienced by HBOT users.

This study offers an approach to hyperbaric oxygen therapy from the standpoint of those who experience it users who need nursing care from the perspective of their needs. Even understanding that the study has limitations as to the number of subjects, it was possible to make a survey of the feelings experienced, contributing to a nursing care focused on the needs of users and their better adaptation to treatment.

\section{METHODS}

This research involved 14 people in HBOT treatment, over 18 years of age, who had already performed at least one HBOT session, having then the knowledge of the procedure to be able to report their experience. Individuals with cognitive impairment, whose health status was considered 
critical or who did not feel comfortable answering questions and participating in the projective dynamics were excluded.

The application of this research occurred in a hyperbaric therapy center, in a city in the interior of the state of Bahia, Brazil, which provides services to people registered with the Unified Health System (SUS, Sistema Único de Saúde), in health plans and by private consultation, coming from several surrounding cities.

Qualitative research allows the study of history, relationships, representations, beliefs, perceptions and opinions that people build about their way of living, thinking and feeling ${ }^{3}$. Because it is a study where the main focus is on feelings, subjective components of the consciousness and the unconscious of the being, of uncontrollable quality and which are not so easily accessed, a multimethod approach was applied ${ }^{4}$.Two projective techniques were used: the free word association test (FWAT) and the drawing-and-story procedure with theme, and, at the end, a semistructured interview was applied. These projective techniques were developed in the psychology area and have been used by other areas, such as health, for the elaboration of researches with a qualitative focus. Because they are simple techniques, which do not require a greater effort of cognition, they can be used in children and people with low schooling, without prejudice to the information collected ${ }^{5}$.

The FWAT consists in a participant, after hearing a word or phrase, writing or speaking another word that comes to his mind. The interviewer launches an inductive stimulus and waits for the free verbal evocation, stored in the memory of the interviewee ${ }^{4}$.

For this technique, two sentences were launched as inductive stimulus: speak five words or phrases when I say "hyperbaric" and speak five words or phrases when I say "hyperbaric and I". Then, the five words or expressions evoked by the interviewee were recorded by the author, obeying the orders of appearance. The choice of this technique allowed the spontaneous access to the universe of feelings of people who use hyperbaric therapy, without them being lost or masked during the collection process.

To ensure that no words or expressions were lost during the FWAT application, a recorder was used to later confirm the recorded evocations.

In the second projective test, a drawing-and-story procedure with a theme, the person is asked to make a drawing that represents that moment they are living. This graphic representation expresses the thoughts and feelings of the person at HBOT and then tells a story about the drawing with beginning, middle and end ${ }^{5}$. The interviewer records the story told and, after the participant hears it, she requests a title for it. For the application of this technique, the researcher made available to the participant craft papers, colored pencils, crayons and hydrographic pens.

To finish the collection, the semistructured interview was used in order to characterize the profile of the participants and relate the projective techniques among them and with the interview, crossing the extracted information and ending the data collection.

The interviews were collected until the saturation of responses was obtained. The saturation criterion for data collection refers to the repetition of similar contents in the participants' speeches without the appearance of new elements and the confirmation of the complementation between the FWAT and the explanations about the drawings.

The participants were guided as to the projective techniques before starting the data collection and were accompanied by the professional during the filling out of the instruments, solving the still existing doubts.

A multitechnical approach was used for the analysis of the content, making it possible to cross-check data that allowed the feelings experienced at HBOT to be portrayed, thus adopting Bardin's thematic content analysis method for the analysis of data from the theme design procedure. To process the FWAT, the words or phrases that appeared most were compiled and repeated between interviews.

The analysis of the drawings-and-story with theme covers the treatment of discursive material produced by the stories, together with the visualization of graphic elements constructed by the participants. From this point of view, story and drawing complement each other, enabling the researcher to access the context in which the narrated experiences were produced ${ }^{5}$.

The recommendations of Resolution 466/2012 of the Brazilian National Health Council were considered in order to respect the rights of the people involved. The research started after the release of the Research Ethics Committee with the registration No. 22026513.4.0000.0053. The anonymity of the interviewees was maintained in order to ensure nonmaleficence, and they were asked to choose a fictitious name to represent them in the study. In order to maintain the privacy of the participants, the interviews were conducted in reserved places, at the hyperbaric clinic itself, and the interviews were previously negotiated so as 
not to interfere with the dynamics of the unit and respect the availability of participants.

\section{RESULTS}

Twelve men and two women participated voluntarily. Age varied between 30 and 79 years.

Six men declared themselves pardos, four white, one black and one yellow. Among the women, 1 called herself white and 1 parda. Regarding the level of education, half of the men and all of the women had a complete second degree.

All participants had a clinical diagnosis related to some kind of skin wound and half had diabetes mellitus as the basic pathology. The number of HBOT sessions performed by the interviewees ranged from 2 to 80 .

After analyzing the testimonies collected in the semistructured interviews, the results of the FWAT application, the drawings and stories produced by the interviewees, the following categories emerged: fear and anxiety; feeling of imprisonment and tiredness; happiness and confidence/hope in therapy and in God.

\section{Feeling of fear}

Fear was represented by the feeling of insecurity before a new procedure, fear of the unknown, fear of machinery, fear of feeling bad and not being rescued.

\begin{abstract}
When I first saw the machine, I was scared. It looked like a ship, a submarine, like they call it, right? [...] Then I felt a little afraid, but then I got used to it...(Hildo, 59 years old).

[...] I was afraid at first, that jittery, and so on, but nowadays I'm calm, it doesn't seem so, right? [...] I don't know..., but then, today I'm relaxed, I don't even worry anymore... (Lourival, 52 years old).
\end{abstract}

Fear is characterized by a mood disorder, worry and emotional disturbance caused by a real or apparent threat or by the presence of something dangerous or strange that has a negative influence on the treatment, affecting from the client's frequency, their cooperation and organic response to confrontations $s^{6,7}$.

It was observed that, after orientation and clarification talk about the procedure, the fear was assuaged. Lack of information or excessive and contradictory information is harmful, generating insecurity and anxiety ${ }^{8}$.
The communication between professionals and the client about the procedure, the machinery and the benefits contribute to the decrease of anxiety and increase of selfconfidence at HBOT. Knowledge through communication is a tool to fight fear?

In order to establish trust, it is fundamental that the professionals, besides explaining and speaking what they believe, it is important that they demonstrate through their actions and conducts a tuning between theory and practice ${ }^{10}$. This relationship between professional and client encompasses much more than technical competence, it encompasses a way of relating through understanding, touch, look, smile, affection, speech and silence, conditioned to an attitude of respect for the other. Treating the patient as a human being inserted in a family, with its own history and culture, full of expectations, fears and needs, allowing him to experience in a singular, safe and calm way the health-disease process ${ }^{10,11}$.

The listening of a professional becomes fundamental to help the client in the elaboration of these feelings, to listen to his fantasies, to guide him to participate actively in his treatment, and it is essential that he can talk about the disease and all the feelings that accompany the diagnosis and treatment ${ }^{11}$.

\section{Feeling of anxiety}

The interviewees reported anxiety due to their curiosity about what the treatment would be like, how the machinery would work and the expectation about the results of the therapy in their diseases.

[...] For me it was a surprise, something new, so I was anxious not to know what it was (Vinicius, 70 years old).

[...] I was a little apprehensive, a little anxious, but I was so anxious about the issue that others were talking about that improves the treatment, that it really has results, so I was anxious to know, right? (Gilvan, 36 years old).

[...] At the moment I had to see what it looked like; I had no idea what it looked like. I had to come here to see what it was like. I was anxious (Lourival, 52 years old).

Anxiety causes internal restlessness and apprehension, associated or not with physical symptoms, which are the result of an expectation created by the client. These symptoms are testimonies of a breakdown of the internal homeostasis 
that manifests itself between the perception of a need and its satisfaction ${ }^{12}$.

In the free word association test, after the stimulus with the word "hyperbaric", the following answers appeared: solution of the problem, illness and chronic wound. For the "hyperbaric and I" stimulus, there were the following responses: healing, change, future, different and activation. These responses complement the feeling of anxiety, because they create the belief that today and the future are related to the cure of their diseases and to a faster recovery, generating anxiety in perceiving the improvement soon.

The patient's fear, anxiety and anguish can act negatively in their adaptation process to the HBOT sector, as well as in relation to the health team and its recovery. In this sense, observing the feelings that are expressed is fundamental for therapeutic listening, humanizing and redeeming respect for human life, considering the social, educational, psychic and emotional circumstances of the individual ${ }^{7-9}$.

\section{Sensation of prison and tiredness}

The HBOT participants reported that the sessions became a kind of prison because of the absence of freedom, the routine of treatment, and the confinement in the chamber that they had to endure in order to finally obtain their total freedom from both the therapy and the wounds that had been accompanying them for years (Fig. 1). In their drawings, the images were characterized by people inside the house, inside a room, in closed circles, demonstrating the sensation experienced of prison to the treatment and the disease.

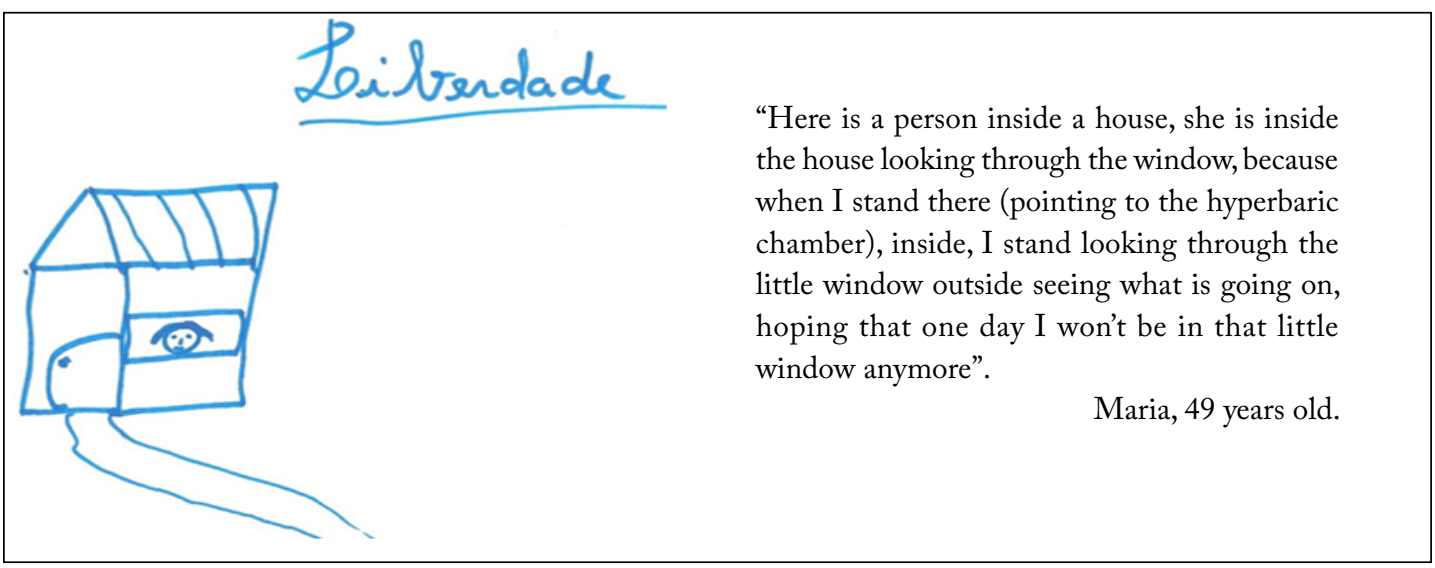

Figure 1. Liberdade.

The way therapy is performed, daily, at fixed times, inside a camera, five times a week, was reported as being tiresome:

I just think it takes too long inside, if it was only an hour for me it would be better, but it's one and a half... Because I am hospitalized, I come and go by private ambulance and waiting is exhausting (Mariana, 62 years old).

Sometimes it makes me tired of being in that position, breathing, breathing, I really want the schedule to finish, I'm actually used to it, having to come, every day, that's the routine! (Maria, 49 years old).

[...] This is tiresome, but we have to pursue it for health, I'm hospitalized and I have hyperbaric, I have hemodialysis, I have to make a sacrifice anyway, if I have to, I'll do it without looking back (Lourival, 52 years old).
The routine experienced by some of the clients who make HBOT is extremely exhausting; besides the daily wear and tear of the therapy, many live in distant towns, others are hospitalized and/or undergo other types of concomitant treatment. The fact that the effectiveness of this therapy is linked to the daily performance of the sessions makes these people seek strength to continue, aiming for healing at the end of therapy.

In the free word association test with the "hyperbaric" stimulus the following sentences appeared: complete and end the sessions, a long time; and with the "hyperbaric and I" stimulus the words: wait, freedom and breath. The words refer to the feeling that everything will end soon, to have the freedom back and be able to "breathe" again.

Long-term treatment for people with chronic diseases generates changes of great importance that impact their lives and the lives of their families and friends. There is the need 
to adapt to the new reality, in face of chronic illness, seeking strategies, such as perceiving the positive side of life, believing in improvement and developing resilience in everyday life ${ }^{13,14}$.

\section{Happiness}

After adapting to the HBOT sessions, the testimonials revealed a feeling of happiness, contentment and well-being. Because it is considered a new therapy for those interviewed, feelings of joy and hope arise in physical recovery:

I felt a joy because it would result positively in my health, I felt more confident, more joy of living! [...] I was happy because I was one of the first to do this treatment here by SUS. And when I arrived here, I felt a welcome, a welcome that gave me confidence, that I could be cured (Emanuel, 30 years old).

Yeah,I felt happy, right? Because I know that this treatment is expensive and I got it so fast by SUS, it was God Himself who helped me, because honestly for me to pay I wouldn't have conditions (Jôjo, 40 years old).
Feelings of well-being and improvement of other pathologies were also reported according to the statements and drawings:

Well, I feel better with oxygen, better than when I enter. The oxygen improves even this pain I feel here in the arm (Val, 64 years old).

Even though I didn't heal the wounds completely, other things worked normally again, like for example, I only had half my lung to breathe, now I can breathe with the whole lung (Emanuel, 30 years old).

It even did me a lot of good for my kidneys, my kidneys started to work very well, I have a little kidney problem, the more I improved it... (Vinícius, 70 years old).

The drawings portray people smiling, face of joy, images of movement, crutch-free, feeling of freedom and happiness, accompanied by speech with positive content and certainty of recovery (Fig. 2).

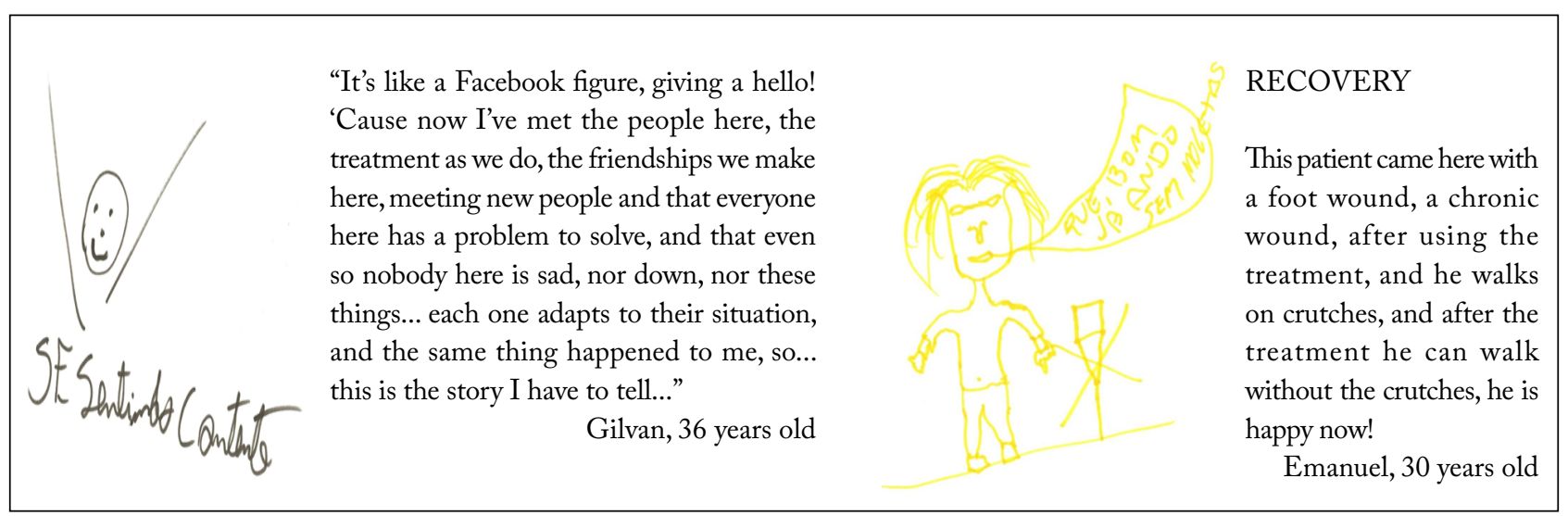

Figure 2. Alegria e recuperação.

In the free word association related to happiness, with the same "hyperbaric" stimulus, there were other responses: health, coziness, well-being and benefits. With the "hyperbaric and I" stimulus appeared: perfect marriage, only one, satisfaction, good feelings.

It is noticeable that there was an improvement in people's daily life after the beginning of the treatment. When the wound and health, in general, improve, consequently the affective marital relationships also benefit ${ }^{8}$. The quality of life of people with chronic illness tends to improve when there is also a feeling of optimism, faith and a personal movement towards their own recovery ${ }^{15}$. After the clients' perception that HBOT has a positive effect, there are changes in their quality of life, having a positive relationship with their physical condition, vitality and social relationships, reflecting on their mental, social and spiritual well-being, providing satisfaction and happiness.

\section{Trust/hope}

This category is subdivided into trust in therapy and trust in God. Trust in therapy is represented by the hope put in the treatment, the expectation of improving and achieving a cure, and the feeling of relief when facing HBOT: 
Today what I feel and that for sure what I thought there at the beginning is real, every day that passes I can see the results in my life (Manuel, 30 years old).

My expectation is this, every day I do I'll be better (Toinho, 60 years old).

The drawing of a house portrays hope in better days, in new expectations for a life free from the wound and its social and emotional repercussions (Fig. 3).

The trust in the therapy was generated by several factors, among them the proof of the effectiveness of the treatment, the results obtained and the interpersonal relationship adopted by the professionals before the users. The welcoming service, the respect for clients'beliefs and the explanation of the entire HBOT process, through a simple and easy-to-understand language, contributed to the satisfaction and confidence.

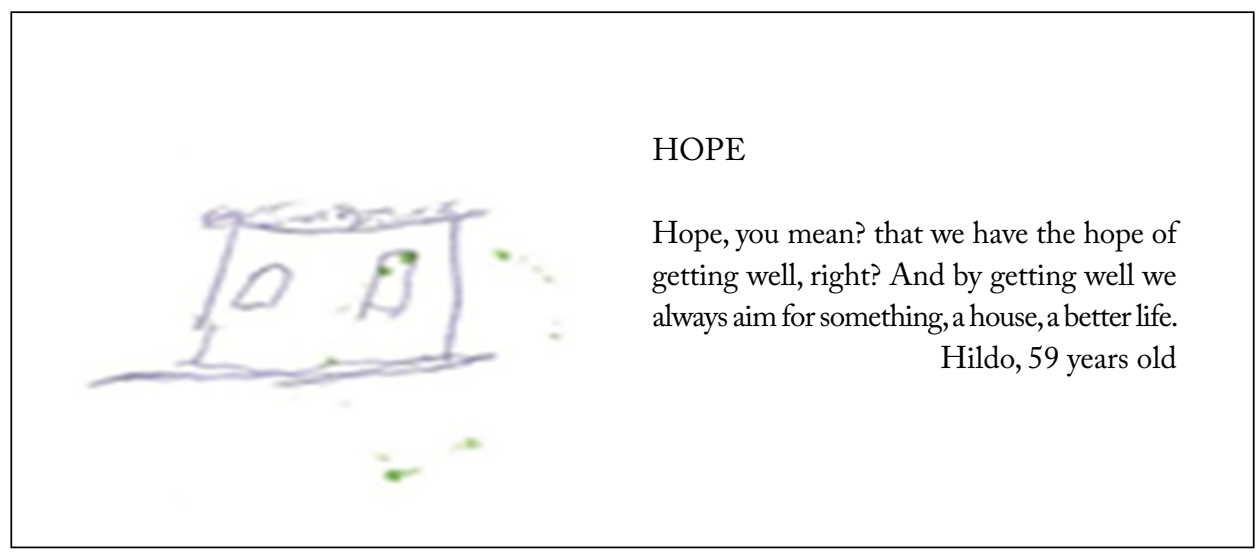

Figure 3. Esperança.

In the case of chronic illness, when there is a trust, the individual will be more willing to talk about his fears and his view of the world, which facilitates the construction of a very important bond between those who care and being cared for ${ }^{15}$.

In the free word association, the topic "trust and hope" was the most responsive to stimuli. For "hyperbaric" appeared: excellent, quality service, effective, great, hope, confidence. For "hyperbaric and I": getting good, getting better for me, benefits, confident, good thing.

Trust and hope, attributed to therapy and to God, were reported by almost all the participants (Fig. 4). Religiosity is intrinsic in the lives of these people, regardless of race, values and beliefs. They deposit in God the opportunity of HBOT and the benefits acquired.

I was very happy... I thank God very much for this opportunity, and that thanks to God I am getting along well (José Lourentino, 67 years old).

It's a new treatment, which I wanted to do a lot to improve my situation, which thank God I did and I'm getting better (Toinho, 60 years old).

I have hope, I trust in God first, and second in hyperbaric. I have hope (Mariana, 62 years old).

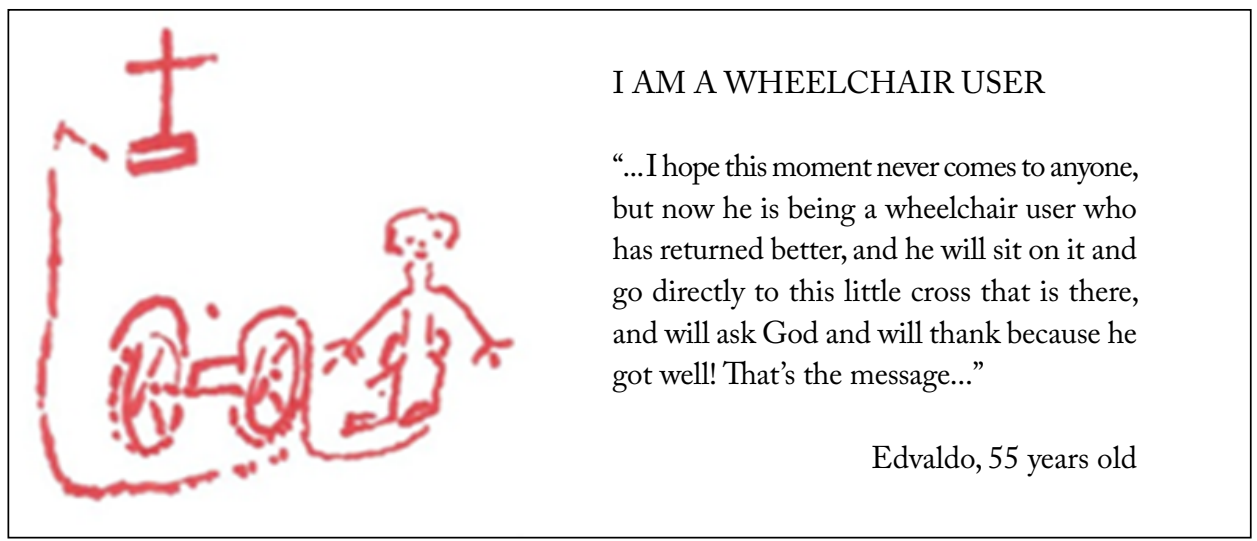

Figure 4. Agradecimento e fé. 
Faith allies to hope and strengthens individuals, who see in God a Supreme Being who daily feeds the desire for improvement and healing, and reduces negative feelings such as fear and anxiety ${ }^{16}$.

The image represents the desire to thank God, affirming religiosity as something present in their daily lives, bringing comfort and hope.

The free word association had few words as responses to stimuli, however well explained. For "hyperbaric": a lot of faith and for "hyperbaric and I": to thank and trust in God.

Faith and trust are a driving force which, together with belief in God, can provide hope for a cure for illness16. Faith in God acts as a positive element in facing the disease. By giving importance to spirituality and religiosity, there is an improvement in the quality of life of these people with health problems. Faith, hope and believing in God contribute to the improvement of the clinical, emotional and spiritual picture.

\section{CONCLUSION}

The negative feelings that emerged in the research, such as the fear present in the speeches, that translate the ignorance of the therapy and the lack of information, and the anxiety, represented by the expectation about a new treatment, the feeling of prison associated to the hyperbaric camera all closed and the long period of sessions, were modified by positive feelings.

After the first sessions and especially after the guidance and incentives from the professionals, the negative feelings were softened and allowed room for the satisfaction for a therapy in which they perceived the results, followed by happiness in being able to return to the familiar and social conviviality, and all this anchored in the feeling of hope and faith.

The study has the limitation of having a specific audience of people with wounds and in a sample of only 14 people, however the multiparametric techniques used deepened the impressions extracted from users.

This study contributes to the knowledge of the feelings of HBOT users, especially those who have chronic and complex wounds that are being treated each day by this method. In this sense, the knowledge about this clientele is broadened, and the nurse, enterostomal therapist or not, can provide differentiated assistance to these people.

\section{ACKNOWLEDGMENTS}

We thank the people with leg ulcers, users of Hiperbárica Feira de Santana who shared their experiences and made this study possible.

\section{AUTHOR'S CONTRIBUTION}

Conceptualization, Machado MSC and Carvalho ESS; Methodology, Machado MSC and Carvalho ESS; Investigation, Machado MSC; Carvalho ESS and Costa CSS; Writing - Original Draft, Machado MSC; Carvalho ESS; Costa CSS and Paranhos RFB; Writing - Review and Editing, Machado MSC; Carvalho ESS; Costa CSS and Paranhos RFB; Supervision, Machado MSC; Carvalho ESS; Costa CSS and Paranhos RFB.

\section{REFERENCES}

1. Chantre C, Foucher S, Le Hot H, Lefort H, Blatteau J-É. Hyperbaric oxygen therapy, a little-known discipline. Rev Infirm. 2018;67(242):14-5. https://doi.org/10.1016/j. revinf.2018.03.012

2. Mathieu D, Marroni A, Kot J. Tenth European Consensus Conference on Hyperbaric Medicine: recommendations for accepted and non-accepted clinical indications and practice of hyperbaric oxygen treatment. Diving Hyperb Med. 2017;47(1):24-32.

3. Minayo MCS. Análise qualitativa: teoria, passos e fidedignidade. Ciênc Saúde Coletiva. 2012;17(3):621-6. https://doi.org/10.1590/S1413-81232012000300007
4. Pinto ER. Conceitos fundamentais dos métodos projetivos. Ágora. 2014;17(1):135-53. https://doi.org/10.1590/S151614982014000100009

5. Coutinho MPL, Nóbrega SM, Catão MFM. Contribuições teórico-metodológicas acerca do uso dos instrumentos projetivos no campo das representações sociais. In: Coutinho MPL, Lima AS, Oliveira FB, Fortunato ML, editores. Representações sociais: abordagem interdisciplinar. João Pessoa: Editora Universitária UFPB; 2003. p.50-66.

6. Perdigon AGC, Strasser G. Dying process and nursing: a relational approach. Theoretical reflections on assistance 
dealing with death. Physis. 2015;25(2):485-500. https://doi. org/10.1590/S0103-73312015000200009

7. Cruickshank S, Steel E, Fenlon D, Armes J, Banks E, Humphris G. Specialist breast cancer nurses' views on implementing a fear of cancer recurrence intervention in practice: a mixed methods study. Support Care Cancer. 2020;28(1):201-10. https://doi.org/10.1007/s00520-019-04762-9

8. Félix RA, Santos RA. Assistência de enfermagem ao paciente submetido à oxigenoterapia hiperbárica. Rev Transformar. 2017;2017:140-51.

9. Hartley BR, Hong C, Elowutz E. Communication in Neurosurgery-The Tower of Babel. World Neurosurg. 2020;133:457-65. https://doi.org/10.1016/j. wneu.2019.08.134

10. Souza NS, Silva CC, Chagas FRC, Silva NF, Silva SV, Souza TSB. Repercussions of care technologies in intensive care units. J Nurs UFPE online. 2018;12(10):2864-72. https://doi. org/10.5205/1981-8963-v12i10a236449p2864-2872-2018

11. Henriques LVL, Dourado MARF, Melo RCCP, Tanaka LH. Implementation of the Humanitude Care Methodology: contribution to the quality of health care. Rev Latino-Am Enfermagem. 2019;27:e3123. https://doi.org/10.1590/15188345.2430-3123
12. Chen H, Cai C, Xie J. The effect of an intensive patients' education program on anxiety, depression and patient global assessment in diabetic foot ulcer patients with Wagner grade 1/2: A randomized, controlled study. Medicine. 2020;99(6):e18480. https://doi.org/10.1097/ MD.0000000000018480

13. Silva GO, Peixoto LCP, Souza DA, Santos ALS, Aguiar ACSA. Repercussions of chronic diseases on the mental health of elderly people. I Nurs UFPE online. 2018;12(11):2923-32. https://doi.org/10.5205/1981-8963v12i11a234540p2923-2932-2018

14. Santos LA, Oliveira PP, Silveira EAA, Gesteira ECR, Fonseca $D F$, Rodrigues AB. The resilience process in family caregivers of people with malignant neoplasia. Esc Anna Nery. 2019; (3):e20190023. https://doi.org/10.1590/2177-9465ean-2019-0023

15. Menezes RR, Kameo SY, Valença TS, Mocó GAA, Santos JMJ. Quality of life related to health and spirituality in individuals with cancer. Rev Bras Cancerol. 2018;64(1):9-17.

16. Kunz JA, Conde CR, Lemos TMR, Barros AES, Ferreira MLSM. A religiosidade e espiritualidade de mulheres com câncer de mama submetidas a tratamento cirúrgico. Rev Enferm Atual In Derme. 2018;86(24). 